\title{
HPLC Method for Determination of Paracetamol in Pharmaceutical Formulations and Environmental Water Samples
}

\author{
NIEF RAHMAN AHMED
}

Department of Environmental Technology, College of Environmental, University of Mosul, Mosul-Iraq

niefpharma@yahoo.com

Received 21 November 2018 / Accepted 20 December 2018

\begin{abstract}
A simple, precise, rapid and accurate reversed phase high performance liquid chromatography method has been developed for the determination of paracetamol in pure from, pharmaceutical formulations and environmental water samples. Chromatography was carried out on supelco $\mathrm{L}_{1}\left(\mathrm{C}_{18}\right)$ reversed- phase column $(25 \mathrm{~cm} \times 4.6 \mathrm{~mm}), 5$ microns, using a mixture of acetonitril: buffer $\mathrm{pH}_{3.0}(40: 60$ $\mathrm{v} / \mathrm{v}$ ) as a mobile phase at a flow rate of $1.5 \mathrm{mLmin}^{-1}$. Detection was performed at $243 \mathrm{~nm}$ at ambient temperature. The retention time was found 2.2 minutes. The calibration curve was linear $(r=0.999)$ over a concentration range from 10 to $100 \mu \mathrm{g} / \mathrm{mL}$. Limit of detection (LOD) and limit of quantitation ( LOQ) were found $3 \mu \mathrm{g} / \mathrm{mL}$ and $9 \mu \mathrm{g} / \mathrm{mL}$ respectively. The method was validated for its linearity, precision and accuracy. The proposed method was successfully applied for the determination of paracetamol in pure form, pharmaceutical formulations and in environmental water samples.
\end{abstract}

Keywords: HPLC, Paracetamol, Pharmaceutical formulations, Environmental water

\section{Introduction}

Paracetamol (acetaminophen or $\mathrm{N}$-acetyl-4-aminophenol), is a popular analgesic and antipyretic agent, with the following structural formula ${ }^{1,2}$ (Figure 1).<smiles>CC(=O)Nc1ccc(O)cc1</smiles>

Figure 1. Structure of Paracetamol (Molecular formula: $\mathrm{C}_{8} \mathrm{H}_{9} \mathrm{NO}_{2}=151.2$ )

Several analytical methods have been devised for the determination of paracetamol. These methods include titrimetric method ${ }^{3}$, HPLC methods ${ }^{4-8}$, HPLC and UV methods ${ }^{9-10}$, HPTLC methods $^{11-14}$, LC methods ${ }^{15-16}$, UV-spectrophotometric methods ${ }^{17-25}$, amperometric method $^{26}$, fluorimetric method ${ }^{27}$, chemiluminescence $\operatorname{method}^{28}$ and voltametric methods ${ }^{29}$. These methods are required expensive or sophisticated instruments and not simple for routine analysis. 
High performance liquid chromatography (HPLC) can be used for determination of drugs and for purposes of control throughout the entire manufacturing process of drugs, as well as quality control of the finished product. It has the advantages of being accurate, sensitive, rapid, selective and reproducible. The present paper reports the development of a new high performance liquid chromatography (HPLC) method for determination of paracetamol in different type of pharmaceutical formulations and environmental water samples.

\section{Experimental}

Chromatographic system consisted of Shimadzu HPLC model LC-20AT with UV detector model SPD-20A and $\mathrm{C}_{18}$ supelco column $(25 \mathrm{~cm} \times 4.6 \mathrm{~mm}), 5 \mu \mathrm{m}$ particle size HPLC condition were given in Table 1.

Table 1. HPLC conditions

\begin{tabular}{lc}
\hline Column & Supelco $\mathrm{C}_{18}(25 \mathrm{~cm} \times 4.6 \mathrm{~mm}), 5 \mu \mathrm{m}$ \\
\hline Wavelength & $243 \mathrm{~nm}$ \\
Mobile phase & Acetonitrile $-\mathrm{pH}_{3}(40: 60)$ \\
Retention time & $2.2 \mathrm{minutes}$ \\
Flow rate & $1.5 \mathrm{~mL} / \mathrm{min}$ \\
Temperature & Ambient \\
Injection volume & $10 \mu \mathrm{L}$ \\
\hline
\end{tabular}

\section{Reagents}

All chemicals used were of analytical or pharmaceutical grade and HPLC grade acetonitrile were used throughout.

\section{Buffer solution $\left(\mathrm{pH}_{3}\right)$}

This solution was prepared by dissolving $5.75 \mathrm{~g}$ of monobasic ammonium phosphate in about $80 \mathrm{~mL}$ of water, add sufficient acetic acid to adjust the $\mathrm{pH}$ to 3 and dilute to $100 \mathrm{~mL}$ by distilled water in a volumetric flask ${ }^{30}$.

\section{Standard stock solution of paracetamol}

$1 \mathrm{mg} / \mathrm{mL}$ of this solution was prepared in mobile phase. Working standard solutions in a range of $10-100 \mu \mathrm{g} / \mathrm{mL}$ were prepared by dilution from stock solution.

\section{HPLC method for determining paracetamol}

A series of standard solution containing $10-100 \mu \mathrm{g} / \mathrm{mL}$ of paracetamol and the sample solution of pharmaceutical preparations were applied respectively. $10 \mu \mathrm{L}$ aliquot of each solution was injected into the column in a duplicate and the chromatograms were recorded. Calibration graph was constructed by plotting the mean peak area versus concentration of paracetamol. The concentration of the unknown was calculated from the regression equation derived from the concentration and peak area data, or was read from calibration graph

\section{Procedures for pharmaceutical preparations}

The recommended condition described above and mentioned in the HPLC method has been applied satisfactorily for determination of paracetamol in different type of pharmaceutical formulations. 


\section{Tablets}

20 tablets were weighed, powdered and transfered an accurately weighed portion of the powder equivalent to $5 \mathrm{mg}$ paracetamol into $100 \mathrm{~mL}$ volumetric flasks and diluted with mobile phase to the volume, and the amount of paracetamol was determined by comparing the peak area of the assay preparation with the standard preparation at the same concentration.

\section{Syrups and drops}

Syrups or drops containing $5 \mathrm{mg}$ of paracetamol was taken into $100 \mathrm{~mL}$ volumetric flasks and diluted with mobile phase to the volume and the amount of paracetamol was determined by comparing the peak area of the assay preparation with the standard preparation at the same concentration.

\section{Suppositories $^{31}$}

Small dish and a glass rod were placed in the dish NLT 5 Suppositories, heated gently on a steam bath until melted, then stirred, cooled while stirring, and weighed. Transfered a weighed portion of the mass, equivalent to $5 \mathrm{mg}$ of paracetamol, to a separator. $30 \mathrm{~mL}$ of solvent hexane was added and dissolved. $30 \mathrm{~mL}$ of water was added, shaken gently and allowed the phases to separate. Transferred the aqueous layer to a $100 \mathrm{~mL}$ volumetric flask, washed the solvent hexane in the separator with three $30 \mathrm{~mL}$ portions of water, adding the washings to the volumetric flask, and dilute with Mobile phase to volume. The amount of paracetamol was determined by comparing the peak area of the assay preparation with the standard preparation at the same concentration.

\section{Procedure for industrial waste water}

To demonstrate the practical applicability of the proposed method, industrial waste water samples from al-hokamaa company for drug industries and medical appliances, Mosul-Iraq, were collected in polyethylene container cleaned with nitric acid and filtered through Whatman No.41 filter paper. Filtered samples were stored at $4{ }^{\circ} \mathrm{C}$ until analyzed which shows negative results, then the samples were spiked with the concentrations ranging from 20-60 $\mathrm{\mu gmL}^{-1}$ of paracetamol and then determined the concentration of paracetamol as described under HPLC method for determining paracetamol. The percentage recovery was calculated using a calibration graph previously prepared.

\section{Results and Discussion}

The development of HPLC methods for the determination of drugs has received considerable attention in recent years because of their importance in the quality control of drugs and pharmaceutical products. The aim of this study was to develop an accurate, sensitive, rapid, selective and reproducible HPLC method for the determination of paracetamol in pure from, its pharmaceutical formulations and industrial wastewater samples using the most commonly employed $\mathrm{L}_{1}$ column with UV detection. The detection wavelength of $243 \mathrm{~nm}$ was chosen in order to achieve a good sensitivity for quantitative determination of paracetamol in tablets, syrups, drops, suppositories and wastewater samples. The mobile phase consisting of acetonitrile : $\mathrm{pH} 3$ (40:60) offered a good separation at ambient temperature under these conditions using a flow rate of $1.5 \mathrm{~mL} / \mathrm{min}$ and retention time of 2.2 minutes as shown in the chromatogram (Figure 2).

Under the described experimental conditions, the analyte peak were well defined and free from tailing paracetamol was determined by measuring the peak area. A plot of peak 
area against concentration gave a linear relationship ( $\mathrm{r}=0.999)$ over the concentration range $10-100 \mu \mathrm{g} / \mathrm{mL}$. Using regression analysis, the linear equation $\mathrm{Y}=3269 \mathrm{x}-203.8$ was obtained where $\mathrm{Y}$ is the mean peak area and $\mathrm{X}$ is the concentration in $\mathrm{mg} / \mathrm{mL}$ (Figure 3, Table 2).

paracetamolo.

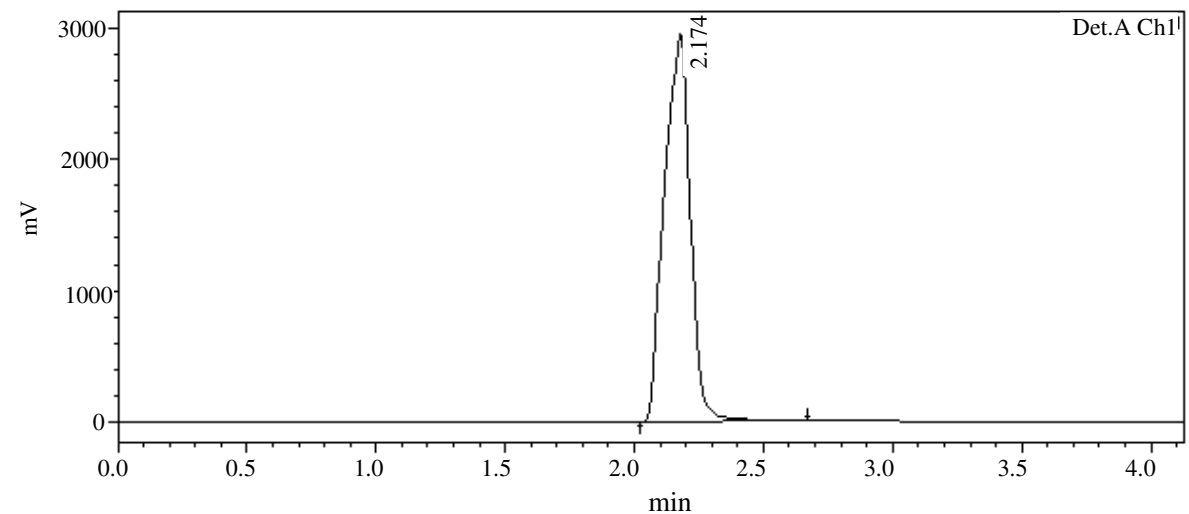

Figure 2 . Typical chromatogram (paracetamole $50 \mu \mathrm{g} / \mathrm{mL}$ )

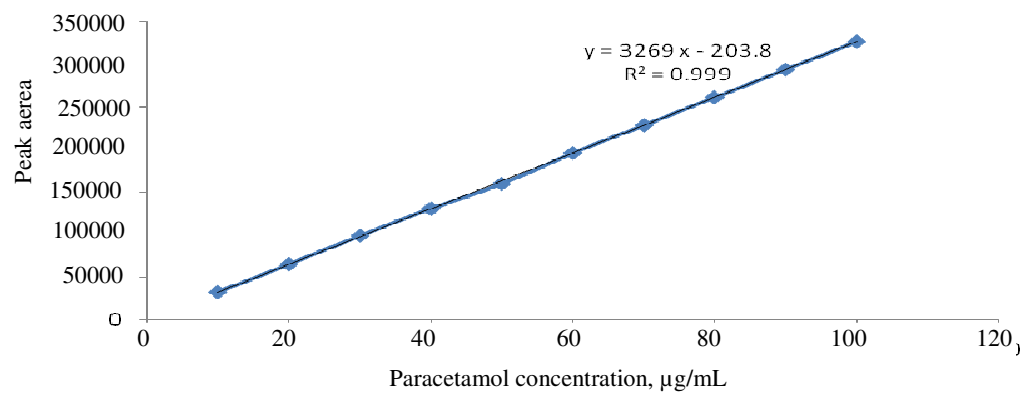

Figure 3. Calibration curve for paracetamol

Table 2. calibration curve data

\begin{tabular}{cccc}
\hline Linearity range & Intercept & $\begin{array}{c}\text { Correlation } \\
\text { coefficient }\end{array}$ & Slope $^{*}$ \\
\hline $10-100 \mu \mathrm{g} / \mathrm{mL}$ & 203.8 & 0.999 & 3269 \\
\hline
\end{tabular}

"Slope: The ratio between the measured quantity in the analytical technique to the concentration of the substance to be determined quantity to the small change in concentration indicate a good sensitivity

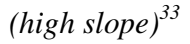

\section{Determination of the limit of detection and limit of quantification (Sensitivity)}

The standard deviation at concentration zero was calculated and this value was used for the calculation of the limit of detection and limit of quantification. The limits of detection (LOD) and quantification (LOQ) were calculated using the following formulae: $\mathrm{LOD}=$ $(3.3 \sigma / \mathrm{s})$ and $\mathrm{LOQ}=(10 \sigma / \mathrm{s})$ where $\sigma$ is the standard deviation of the response and $\mathrm{s}$ is the slope of the regression line ${ }^{32}$. Limit of detection (LOD) and limit of quantification (LOQ) were found $3 \mu \mathrm{g} / \mathrm{mL}$ and $9 \mu \mathrm{g} / \mathrm{mL}$ respectively. The results indicate that the method was sensitive enough to detect a concentration of $3 \mathrm{ng} / \mathrm{mL}$ and able to quantify at a concentration of above $9 \mu \mathrm{g} / \mathrm{mL}$. 


\section{Precision and accuracy}

The precision of the method was established by carrying out the analysis of paracetamol $(n=6)$ using the proposed method. The low value of standard deviation showed that the method was precise. The results obtained are presented in Table 3. To ensure the reliability and accuracy of the method recovery studies were carried out at five different levels. The results of recovery studies were found to be accurate, mean recoveries being 100.51 1.09 $(\mathrm{n}=6)$ as shown in Table 3.

Table 3. Method accuracy and precision

\begin{tabular}{ccc}
\hline Concentration of paracetamol, $\mu \mathrm{g} / \mathrm{mL}$ & RSD $\%$ & Recovery\% \\
\hline 10 & 0.92 & 101.6 \\
20 & 0.85 & 100.5 \\
40 & 1.18 & 101.0 \\
80 & 1.06 & 99.95 \\
100 & 0.80 & 99.5 \\
Mean $(\mathrm{n}=6)$ & 0.962 & 100.51 \\
\hline
\end{tabular}

\section{Analytical application}

The proposed method was successfully applied to the assay of paracetamol in pharmaceutical formulations (tablets, syrups, drops and suppositories ) and industrial waste water sample. The result of analysis for pharmaceutical formulation Table 4, which reveals that there was close agreement between the results obtained by the proposed method and label claim.

Table 4. Determination of paracetamol in pharmaceutical formulations

\begin{tabular}{|c|c|c|c|}
\hline Pharmaceutical formulations & Label amount, mg & Found, mg & $($ Recovery \%) \\
\hline Colden tablet(NDI) & $450 \mathrm{mg} / \mathrm{tab}$ & 451.8 & 100.4 \\
\hline Antispasmine tablet(NDI) & $350 \mathrm{mg} / \mathrm{tab}$ & 349.65 & 99.9 \\
\hline Flu-out tablet(HPI) & $350 \mathrm{mg} / \mathrm{tab}$ & 349.58 & 99.88 \\
\hline Algesic tablet(HPI) & $350 \mathrm{mg} / \mathrm{tab}$ & 348.0 & 99.42 \\
\hline Paracetamol tablet(HPI) & $500 \mathrm{mg} / \mathrm{tab}$ & 495.6 & 99.12 \\
\hline Paradin tablet(NDI) & $325 \mathrm{mg} / \mathrm{tab}$ & 328.4 & 101.04 \\
\hline Antipyrol syrup(NDI) & $120 \mathrm{mg} / 5 \mathrm{~mL}$ & 119.0 & 99.16 \\
\hline Antipyrol drop(HPI) & $100 \mathrm{mg} / \mathrm{mL}$ & 99.3 & 99.3 \\
\hline Coldin syrup(NDI) & $120 \mathrm{mg} / 5 \mathrm{~mL}$ & 122.2 & 101.83 \\
\hline Anti pyrol & $120 \mathrm{mg} / \mathrm{supp}$ & 121.1 & 100.91 \\
\hline \multirow[t]{2}{*}{ suppositories(HPI) } & $250 \mathrm{mg} / \mathrm{supp}$ & 248.5 & 99.4 \\
\hline & $500 \mathrm{mg} / \mathrm{supp}$ & 496.9 & 99.38 \\
\hline
\end{tabular}

* Mean of six determinations

The results of industrial wastewater samples is presented in Table 5. It shows that the recovery values obtained were closed to $100 \%$.

Table 5. Determination of paracetamol in industrial wastewater samples

\begin{tabular}{cccc}
\hline \multirow{2}{*}{ Water sample } & \multicolumn{2}{c}{ Paracetamol, $\mu \mathrm{g} / \mathrm{mL}^{\star}$} & \multirow{2}{*}{ Recovery\% } \\
\cline { 2 - 3 } & Taken & Found & \\
\hline \multirow{3}{*}{ Industrial wastewater } & 20 & 20.0 & 100 \\
& 40 & 40.6 & 101.5 \\
& 60 & 60.4 & 100.6 \\
\hline
\end{tabular}

${ }^{\star}$ Mean of ten determinations. 


\section{Comparison of methods}

The proposed method was compared with other reported HPLC methods. Table 6 shows the comparison between the present method and another HPLC methods. The present method is more applications than other reported HPLC methods.

Table 6. Comparison of the existing HPLC methods with the proposed method

\begin{tabular}{|c|c|c|c|c|}
\hline Parameters & Method 1 & Method 2 & Method 3 & Method 4 \\
\hline Ref & [4] & [5] & [6] & Proposed \\
\hline Column & $\mathrm{C}_{18}$ & $\mathrm{C}_{18}$ & $\mathrm{C}_{18}$ & $\mathrm{C}_{18}$ \\
\hline Wavelength, nm & 243 & 240 & 210 & 243 \\
\hline $\begin{array}{c}\text { Linear range } \\
\mu \mathrm{g} / \mathrm{mL}\end{array}$ & $10-100 \mu \mathrm{g} / \mathrm{mL}$ & $5-120 \mu \mathrm{g} / \mathrm{mL}$ & $100-1000$ & $10-100 \mu \mathrm{g} / \mathrm{mL}$ \\
\hline Mobile phase & $\begin{array}{l}\text { Methanol- } \\
\mathrm{H}_{2} \mathrm{O}(40: 60)\end{array}$ & $\begin{array}{c}\mathrm{H}_{2} \mathrm{O} \text {-Acetonitrile } \\
-(85: 15)\end{array}$ & $\begin{array}{c}\text { Acetonitile } \\
(\mathrm{pH} 2.5)(15: 85)\end{array}$ & $\begin{array}{c}\text { Acetonitrile }-\mathrm{pH} \\
3.0(40: 60)\end{array}$ \\
\hline $\begin{array}{l}\text { Retention time. } \\
\text { (minutes) }\end{array}$ & 3.03 & 1.5 & 5.5 & 2.2 \\
\hline Flow rate & $1.0 \mathrm{~mL} / \mathrm{min}$ & $1.0 \mathrm{~mL} / \mathrm{min}$ & $1.0 \mathrm{~mL} / \mathrm{min}$ & $\begin{array}{c}1.5 \mathrm{~mL} / \mathrm{min} \\
\text { Tablets ,Syrups, }\end{array}$ \\
\hline Application & Tablets & Tablets & Tablets & $\begin{array}{l}\text { drops, Suppositories } \\
\text { and industrial } \\
\text { wastewater }\end{array}$ \\
\hline
\end{tabular}

\section{Conclusion}

In this study, accurate, simple and rapid HPLC method was developed and validated for the determination of paracetamol in pharmaceutical formulations and industrial waste water samples. The method was selective using $\mathrm{L}_{1}$ analytical column and applicable to pharmaceutical preparations. Thus the developed method was recommended for control throughout the entire manufacturing process of drugs as well as quality control of the finished product in view of its high recovery and precision.

\section{Acknowledgment}

The author (Dr. Nief Rahman Ahmad) wishes to express gratitude to the Al-hokamaa state company of drug industries and medical appliance (HDI) Nineveh - Iraq for providing gift samples of paracetamol standard materials and pharmaceutical preparations and for permission and facilities to carry out the research work.

\section{References}

1. The pharmaceutical codex, Incorporating the British pharmaceutical codex, $11^{\text {th }}$ Edn., Pharmaceutical Press, London 1979, 638-641.

2 Sweetman S C, Editor, Matindale-The Complete Drug Reference. $36^{\text {th }}$ Edn., London: Pharmaceutical Press; 2009, p.108, 1895.

3. British Pharmacopoeia, H. M. Stationery office, London, UK, 2013, 1700.

4. Chandra R and Sharma D K, Int J Chromatogr Sci., 2013, 3(2), 31-34

5. Hamad M. Adress Hasan, Ibrahim H. Habib and Amira A. Khatab, Eur Chem Bull., 2017, 6(7), 330-335; DOI:10.17628/ecb.2017.6.330-335

6. Maslarska A and Tencheva J, Int J Pharm Pharm Sci., 2013, 5(2), 417-419.

7. Kalin V, Lyudmil K and Gjorgji P, Der Pharmacia Sinica, 2013, 4(1), 102-105. 
8. Suryan A, Bhusari V, Rasal K and Dhaneshwar S, Int J Pharm Sci Drug Res, 2011, 3(4), 303-308.

9. Ashraful S, Abuzar S and Kumar P, Int J Pharm Life Sci., 2011, 2(12), 1267-1275.

10. Ashraful S, Shultana S, Sayeed M and Dewan I, Int J Pharm., 2012, 2(1), 39- 45.

11. Uchadadiya N, Mehta F and Sanchaniya P, Chromatography Research International, 2013, 2013, 1-6.

12. Yadav A, Singh R, Mathur S, Saini P and Singh G, J Planar Chromatogr., 2009, 22(6), 421-424.

13. Deshpanday P B, Gandhi V S and Bhangale S Y, J Pharma Biomed Anal., 2010, 3, 1-5.

14. Baheti K, Shaikh S, Shah N and Dehghan M, Int J Res Pharm Biomed Sci., 2011, 2(2), 672-675.

15. Monser L and Darghouth F, J Pharmd Biomed Anal., 2002, 27(6), 851-860; DOI:10.1016/S0731-7085(01)00515-5

16. Sultana N, Saeed Arayne M and Nadir Ali S, American J Anal Chem., 2013, 4(1), 2433; DOI:10.4236/ajac.2013.41004

17. Kondawar M, Shah R, Waghmare J, ShahN and Malusare M, Int J PharmTech Res., 2011, 3(3), 1603-1608.

18. Farha Khalaf Omar, Iraqi Nat J Chem., 2014, 53, 36-42.

19. Mahaparale S, Telekone R, Raut R, Damle S and Kasture P, Indian J Pharm Sci., 2010, 72(1),133-136; DOI:10.4103/0250-474X.62241

20. Shariati R, Irandous Mt, Amin N and Ahmadi F, Current Pharm Anal., 2013, 9(2), 183-190; DOI:10.2174/1573412911309020009

21. Ahmad M. El-Zinati and Monzir S. Abdel-Latif, Open Anal Chem J., 2015, 8, 1-6

22. Babar S, Mane V and Bhise S, Int J Pharm Pharma Sci., 2012, 4(4), 206-209.

23. Anandakumar $\mathrm{K}$ and Veerasundari P, ISRN Spectros., 2014, 1-8; DOI:10.1155/2014/248960

24. Rashmi A, Int J Pharm Life Sci., 2013, 4(3), 2444-2446

25. Patel, Shah R, Kadikar H, Patani P and Shukla M, Int J Pharm Res Bio Sci., 2012, 1(1), 1-19.

26. Prabakar S and Narayanan S, Talanta, 2007, 72(5), 1818-1827; DOI:10.1016/j.talanta.2007.02.015

27. Martinez E J L, Satinsky D, Solich P, Barrales P O and Molina A D, J Pharm Biomed Anal., 2007, 45(2), 318-321; DOI:10.1016/j.jpba.2007.05.004

28. Wirat R, Liawruangrath S and Townshend A, Talanta, 2006, 69(4), 976-983; DOI:10.1016/j.talanta.2005.11.050

29. Anitha Kumary V, Divya J, Mary NancyT E and Sreevalsan K, Int J Electrochem Sci, 2013, 8, 6610-6619.

30. British Pharmacopeia, Her Majesty, Stationary Office, London, 2009, 5107.

31. The United State Pharmacopeia Convection, Inc, 33-NF, 2010, 28, 2495.

32. Laxman S, Bala P, Anil M, Nandini P and Nancy P, J Chem Pharm Res., 2011, 3(4), 937-944.

33. Kenneth A C M, A Textbook of pharmaceutical Analysis, $3^{\text {rd }}$ Edn. John Wiley and Sons, New York., 1982, 620. 